\title{
REVIEW
}

\section{Critical care - where have we been and where are we going?}

\author{
Jean-Louis Vincent*
}

\begin{abstract}
The first ICUs were established in the late 1950s and the specialty of critical care medicine began to develop. Since those early days, huge improvements have been made in terms of technological advances and understanding of the pathophysiology and pathogenesis of the disease processes that affect critically ill patients. Progress in therapeutics has been less dramatic, but process of care has improved steadily with important changes, including less iatrogenicity, better communication with patients and families, and improved teamwork, which have helped improve outcomes for ICU patients. Critical care medicine is one of the fastest-growing hospital specialties and, looking back, it is clear just how far we have come in such a relatively short period of time. With the ICU set to occupy an increasingly important place in hospitals worldwide, we must learn from the past and wisely embrace new developments in technology, therapeutics, and process, to ensure that the goals of critical care medicine are met in the future.
\end{abstract}

When I want to understand what is happening today or try to decide what will happen tomorrow, I look back.

Omar Khayyam

\section{Introduction}

Looking back over the years since the first ICUs were developed, we can clearly see how critical care medicine has developed in terms of technology, with modern respirators replacing the bulky iron lungs of the past, modern ultrasound machines providing instant imaging at the bedside, and modern monitoring systems enabling non-invasive assessment of multiple variables. Particularly

*Correspondence: jlvincen@ulb.ac.be

Department of Intensive Care, Erasme University Hospital, Université libre de Bruxelles, Route de Lennik 808, 1070 Brussels, Belgium striking also have been the improvements in our understanding of diseases and their pathophysiology. Advances in therapeutics have been less dramatic and are less obvious, but are nevertheless present; there have perhaps not been many (or any) dramatic changes that have altered critical care practice overnight, but, rather, evolution has come in a succession of small forward-moving steps [1]. The process of care has also evolved slowly but surely and the changes here have perhaps had the greatest impact on outcomes, with improved teamwork and specialist training, reduced iatrogenicity, earlier patient mobilization, more personal care of the patient and their families, and so forth.

In this article we will look back at where we have come from before briefly reflecting on where critical care medicine is likely to be going in the future.

\section{Critical care: the past}

The concept of critical care and realization of the need for a separate specialty in terms of medical and nursing skills and physical unit position evolved over time as it gradually became apparent that seriously ill or injured patients could benefit from closer attention than was provided to less severely ill patients; this growing realization came at a time when improvements in technology, monitoring, and therapeutics were enabling greater numbers of such patients to survive.

There are several key figures and events commonly associated with the origin of critical care medicine and development of ICUs [2,3], although many other unrecognized individuals have certainly contributed to the development of this field. During the Crimean War in the 1850s, Florence Nightingale demanded that the most seriously ill patients were placed in beds near to the nursing station so that they could be watched more closely, creating an early focus on the importance of a separate geographical area for critically ill patients. In 1923, Dr Walter E Dandy opened a special three-bed unit for the more critically ill postoperative neurosurgical patients at the Johns Hopkins Hospital in Baltimore, MD, USA, using specially trained nurses to help monitor and manage them. In 1930, Dr Martin Kirschner designed and built a combined postoperative recovery/intensive 
care ward in the surgical unit at the University of Tubingen, Germany. Other surgical units followed these examples, such that by 1960 almost all hospitals had a recovery unit attached to their operating rooms.

During the Second World War, specialized shock units were used to provide efficient resuscitation for the large numbers of severely injured soldiers. In the 1950s, several large polio epidemics, notably in Copenhagen, led to the opening of respiratory units for the many patients requiring mechanical ventilation. In 1958, Dr Max Harry Weil and Dr Hebert Shubin opened a four-bed shock ward in LA County - USC Medical Center, Los Angeles, CA, USA to improve the recognition and treatment of serious complications in critically ill patients. That same year, Dr Peter Safar opened a multidisciplinary ICU at Baltimore City Hospital. Over the next decade or so, ICUs began to be created in hospitals across Europe, the USA, and Australasia. In other countries, ICUs are a more recent development - for example, the first ICU in China was established in 1982 [4].

Early ICUs were somewhat isolated, slightly mysterious, and rather frightening places; staff and visitors (when allowed) were often gowned with protective shoe covers, even masks - adding to the sense of anxiety for the patient and their families. Patients were often heavily sedated to facilitate mechanical ventilation and in the belief that this approach would reduce patient agitation and discomfort. Visiting hours were highly restricted to avoid any increase in physiologic stress for the patient, any interference with the provision of care, and to limit the spread of infection in these vulnerable patients [5].

Many of the initial critical care units were staffed by physicians whose primary specialties were in anesthesiology or internal medicine. Often hospitals had separate surgical and medical ICUs, and some, particularly in the USA, also developed specialty respiratory, cardiac, and neurosurgical ICUs. The majority of units were open, with patients managed by their primary admitting physician, so that different patients on a single ICU would be managed by different physicians. Later, it was realized that many ICU patients had similar problems, regardless of the reason for their critical illness, and that closed units, in which patients were managed by a team of specially qualified intensive care physicians and nurses, provided patients with better care and were associated with improved outcomes [6,7]. The important role of the intensivist in maximizing patient outcomes was also recognized [8], and specialist training programs began to develop as intensive care medicine became a specialty in its own right.

As ICUs began to expand and ever-sicker patients were being admitted and observed, the quantity of critical care research being conducted also increased and understanding of the mechanisms of critical illness progressed rapidly. With continuing developments in technology came more sophisticated life-support and invasive monitoring techniques. Management of the intensive care patient was increasingly interventional. Invasive monitoring systems, notably the pulmonary artery catheter, were widely used. Fluid administration, blood transfusions, oxygen administration, and vasopressors became essential parts of the intensivist's therapeutic armamentarium, although the use of these interventions was often supported by relatively little sound clinical evidence.

\section{Critical care: the present}

The present ICU is unrecognizable from that of 40 years ago in terms of technology. Mechanical ventilators are much smaller, more mobile, and more user-friendly. The development of portable ultrasound units and other noninvasive or less-invasive monitoring techniques has decreased the need for pulmonary artery catheter insertion [9]. The focus of critical care has also shifted somewhat, with patient management becoming less invasive whenever possible, less interventional, and more humane. Despite some initial reluctance, particularly from nursing staff, many units now allow unrestricted or slightly restricted visiting as the benefits of contact with family and loved ones have been recognized [10], although this is not yet a universal finding [11-13]. Nevertheless, units are generally much less strict and more friendly and welcoming for the patient and family than in the past. Improved communication with patients and their families is now part of daily practice and the importance of involving the patient and family in decision-making, especially at the end of life, is also stressed, replacing the more paternal approach of the past [14]. The need for a multidisciplinary approach to patient care is also recognized, and increasingly nutritionists, physiotherapists [15], pharmacists [16], infectious disease consultants [17], and members of other relevant specialties are regularly included in patient rounds. The increasing incidence of microorganisms resistant to currently available antimicrobial agents has led to creation of local, regional, and international surveillance systems to monitor antibiotic resistance and microbiology patterns. Large hospital-wide infection prevention schemes, focusing largely on increased awareness and improved hand-hygiene, have also been established to limit development of nosocomial infections.

The renewed interest in evidence-based medicine in the early 1990s focused a rethink of many accepted practices within the ICU as the lack of solid, high-level evidence for many of these interventions began to be appreciated. Well-designed, randomized trials began to evaluate established procedures, including, for example, the pulmonary artery catheter, blood transfusions, the 
use of albumin, and so forth. The results from some of these studies suggested that much of the morbidity associated with critical care was, in fact, iatrogenic and that some interventions may do more harm than good. For example, blood transfusion triggers could be reduced to lower levels than the widely used $10 \mathrm{~g} / \mathrm{dl}$ cutoff value [18]; high tidal volumes were shown to be detrimental [19]; the administration of low-dose dopamine to prevent renal failure was shown to be of no benefit [20]; routine insertion of the pulmonary artery catheter was associated with no benefit and increased complications and costs [21]; and excess sedation was associated with worse outcomes [22]. The development of large national and international critical care consortia - such as the ANZICS clinical trials group, the Acute Respiratory Distress Syndrome Network, and the Canadian Critical Care Trials Group - has facilitated such studies and our evidence base is beginning to expand, with data from large-scale observational studies fueling the continued development of multicenter randomized trials. Importantly, widespread use and availability of Internet technology means that results of such studies are now transmitted more rapidly around the globe.

Whereas trials of established interventions have helped improve patient management, studies of potential new therapies, notably for patients with sepsis, have been frustratingly negative. Repeatedly, new approaches have failed to live up to the promise shown in preclinical or single-center studies: tight glucose control [23,24], moderate-dose steroids in septic shock $[25,26]$, and activated protein $C[27,28]$, to name just a few. Attempts have been made to develop clearer definitions of complex ICU syndromes, such as sepsis [29] and acute respiratory distress syndrome [30], in order to try and reduce heterogeneity in the populations of patients selected for clinical trials and increase the likelihood of demonstrating efficacy. Severity scores [31-33] and staging systems $[29,34]$ have also been proposed to better characterize ICU patients and study populations.

The vast amounts of data generated from the everincreasing number of studies conducted and published, and a belief that standardizing approaches to patient management may improve patient outcomes, have led to a surge in the numbers of guidelines developed by international groups or societies. Guidelines for sepsis management [35], nutrition [36], red blood cell transfusion [37], ICU design [38], and many other aspects of critical care structure and process have all been published. The use of locally produced or adapted protocols has also been encouraged and these are now present on many ICUs, although the use of checklists, such as FASTHUG [39], may represent a more flexible approach to individual patients, particularly in units with adequate numbers of well-trained staff.

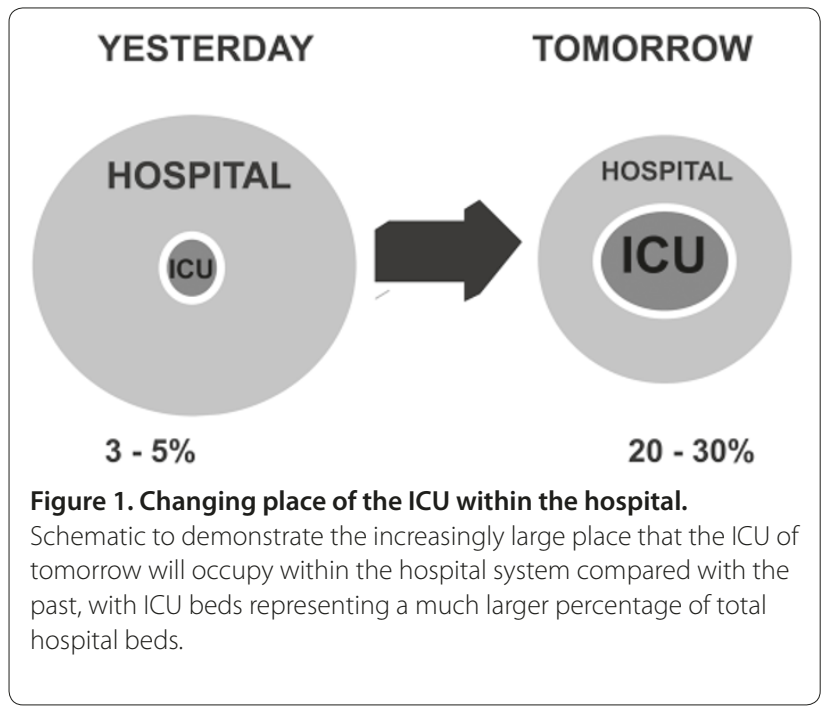

Many hospitals have begun to spread intensive care beyond the fixed walls of the ICU, with the creation of so-called medical emergency teams or rapid response teams. The primary purpose of these teams of intensive care-trained staff is to attend, assess, and provide treatment for deteriorating patients on the ward before they reach a state where ICU admission is needed, thus hopefully improving outcomes and creating more efficient ICU bed usage.

\section{Critical care: the future}

In 2010 Halpern and Pastores published a review of the evolution in critical care medicine in the United States between 2000 and 2005 [40]. During this time period there was a $4 \%$ decrease in the total number of hospital beds, but the number of ICU beds increased by $7 \%$. Hospital non-ICU inpatient days increased by $5 \%$, but ICU inpatient days increased by $10 \%$. Annual critical care medicine costs increased by $44 \%$, but the proportion of hospital costs and national health expenditures allocated to critical care medicine decreased by $1.6 \%$ and $1.8 \%$, respectively, over this time period. As the need for intensive care continues to increase, the ratio of ICU beds to hospital beds will continue to rise as the ICU occupies an ever-larger role at the center of acute hospital care (Figure 1).

A key challenge for the future will be to provide adequately trained medical and paramedical staff to cater for the increased numbers of patients, especially as studies have identified large predicted shortfalls in trained intensivists [41]. To deal with the shortages in physician cover, several options have been proposed - including greater use of computerized, nurse-run protocols to manage patients (but the numbers of nursing personnel would then need to be increased to compensate for their 


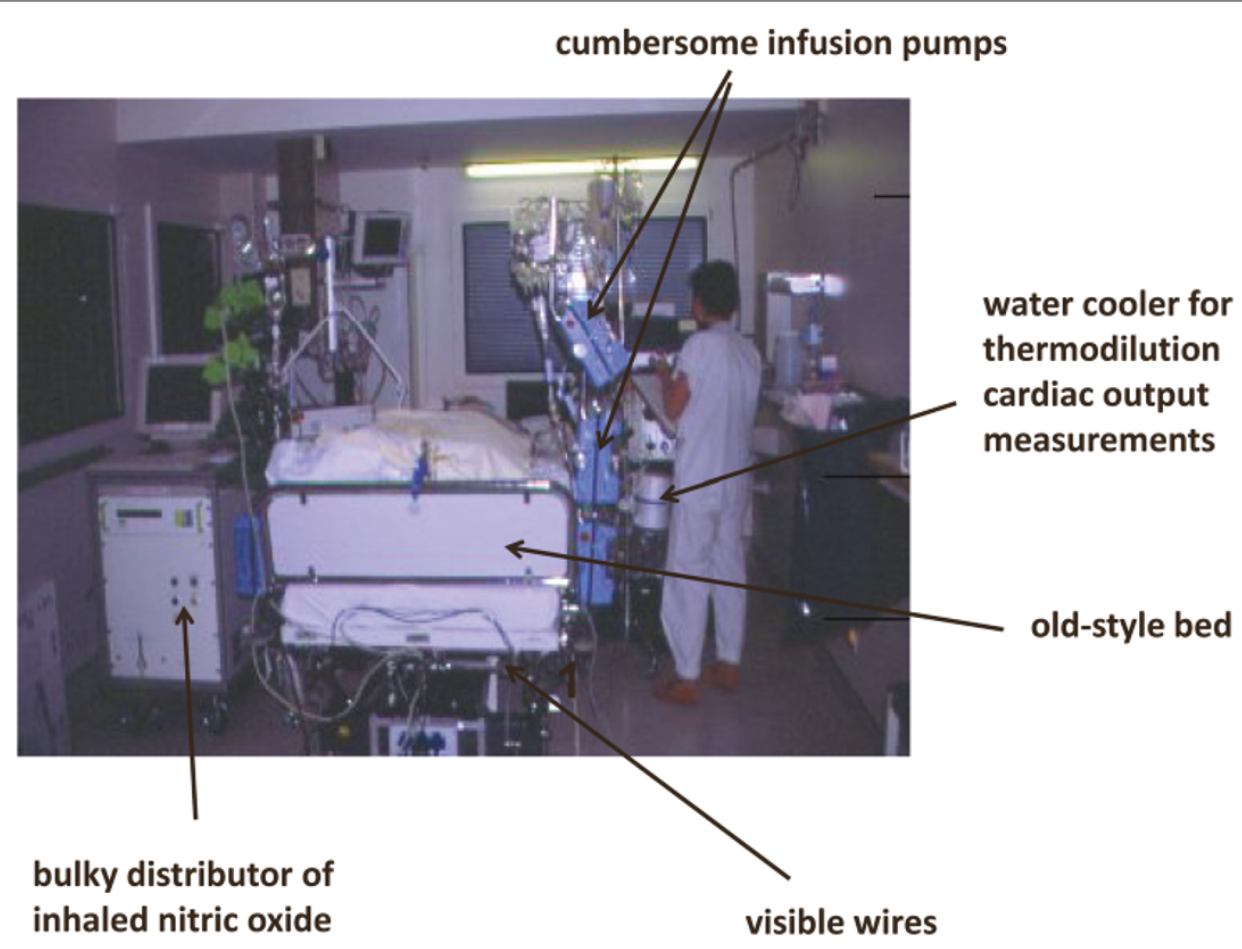

Figure 2. Our ICU, 20 years ago!

extra workload); regionalization of intensive care so that trained staff are concentrated in several larger units, which will provide greater staffing flexibility and may offer improved patient outcomes [42]; and use of telemedicine to enable a trained doctor from a larger institution to provide assistance to less well-staffed, smaller units [43]. A combination of these approaches will probably be needed along with effective admission and discharge criteria to limit use of ICU beds for those who will really benefit from them and financial, academic, and job satisfaction incentives to encourage young physicians to move into critical care [1].

In terms of technology, electronic tools and information technology will play an ever-important role in daily medical practice. Patient records will be immediately available online wherever in the world the patient may find themselves. Prescriptions and tests will be increasingly ordered, viewed, and analyzed via handheld digital assistants or bedside screens, facilitating diagnosis and helping to limit drug errors. Technological advances will clearly play a large part in future medical development, as they have done in the past. Continued developments in genomics, proteomics, and metabolomics will lead to better characterization of patients and their ongoing and underlying disease processes, facilitating diagnosis, prognosis, and therapeutics. These techniques will allow patient care to be increasingly individualized, with treatments chosen according to specific factors within each patient. Continued study will also reveal better treatment targets, which may include microcirculatory measures, cellular markers, and so forth. A multidisciplinary ICU team will become the norm, covering all aspects of patient care from medical therapies and nursing care through to nutritional advice and psychological support. The borders between emergency care and intensive care will become less obvious as early diagnosis and timely resuscitation and treatment move into the pre-ICU arena. Although ICU and hospital survival will of course remain important outcome measures, other more patient-relevant factors, including longer-term outcomes and quality of care measures, will become as important in assessing outcomes. Post-ICU follow-up will also become more common as the negative longer term effects of intensive care are appreciated.

\section{Conclusion}

Critical care medicine has evolved over the years in terms of structure (Figure 2), process, and outcomes. Fewer and less-invasive interventions, more humane care, earlier diagnosis and treatment, expansion of the service beyond the physical walls of the ICU, and better national and international collaborations with colleagues across the globe are just some of the many changes that we have witnessed since the first ICUs were developed some 60 years ago. Critical care medicine is one of the fastestgrowing medical fields in terms of patient numbers, and 
represents an increasingly important part of healthcare systems in the developed world. Critical care medicine is also more slowly beginning to have a presence in developing countries, and one of the current challenges is to ensure adequate funding, training, and equipment for these newer members of the critical care arena.

We have come a long way but still have some distance to cover as we strive to ensure that critical care medicine provides effective, efficient, evidence-based care to all who need it.

\section{Competing interests}

The author declares that he has no competing interests.

\section{Declarations}

This article has been published as part of Critical Care Volume 17 Suppl 1, 2013: Future of Critical Care Medicine. The supplement was proposed by Fresenius Kabi based on presentations from the 'Future of critical care medicine (FCCM) 2012: Today's practice and a look to the future' symposium. Articles were commissioned by the journal, were independently prepared by the authors and have been peer reviewed by the journal. Publication of the supplement was supported by Fresenius Kabi.

Published: 12 March 2013

\section{References}

1. Vincent JL, Singer M, Marini JJ, Moreno R, Levy M, Matthay MA, Pinsky M, Rhodes A, Ferguson ND, Evans T, Annane D, Hall JB: Thirty years of critical care medicine. Crit Care 2010, 14:311.

2. Hilberman M: The evolution of intensive care units. Crit Care Med 1975 3:159-165.

3. Ristagno G, Weil MH: History of critical care medicine: the past, present and future. In Intensive and Critical Care Medicine. Edited by Gullo A, Lumb PD, Besso J, Williams GF. Milan: Springer-Verlag; 2009:3-17.

4. Du B, Xi X, Chen D, Peng J: Clinical review: Critical care medicine in mainland China. Crit Care 2010, 14:206

5. Berwick DM, Kotagal M: Restricted visiting hours in ICUs: time to change. JAMA 2004, 292:736-737.

6. Carson SS, Stocking C, Podsadecki T, Christenson J, Pohlman A, MacRae S, Jordan J, Humphrey $\mathrm{H}$, Siegler M, Hall J: Effects of organizational change in the medical intensive care unit of a teaching hospital: a comparison of 'open' and 'closed' formats. JAMA 1996, 276:322-328.

7. Ghorra S, Reinert SE, Cioffi W, Buczko G, Simms HH: Analysis of the effect of conversion from open to closed surgical intensive care unit. Ann Surg 1999, 229:163-171.

8. Pronovost PJ, Angus DC, Dorman T, Robinson KA, Dremsizov TT, Young TL: Physician staffing patterns and clinical outcomes in critically ill patients: a systematic review. JAMA 2002, 288:2151-2162.

9. Vincent $J$, Rhodes A, Perel A, Martin GS, Della RG, Vallet B, Pinsky MR, Hofer CK, Teboul JL, de Boode WP, Scolletta S, Vieillard-Baron A, De BD, Walley KR, Maggiorini M, Singer M: Clinical review: Update on hemodynamic monitoring - a consensus of 16. Crit Care 2011, 15:229.

10. Fumagalli S, Boncinelli L, Lo NA, Valoti P, Baldereschi G, Di BM, Ungar A, Baldasseroni S, Geppetti P, Masotti G, Pini R, Marchionni N: Reduced cardiocirculatory complications with unrestrictive visiting policy in an intensive care unit: results from a pilot, randomized trial. Circulation 2006, 113:946-952.

11. Giannini A, Miccinesi $G$, Leoncino S: Visiting policies in Italian intensive care units: a nationwide survey. Intensive Care Med 2008, 34:1256-1262.

12. Spreen $A E$, Schuurmans MJ: Visiting policies in the adult intensive care units: a complete survey of Dutch ICUs. Intensive Crit Care Nurs 2011 27:27-30

13. Hunter JD, Goddard C, Rothwell M, Ketharaju S, Cooper H: A survey of intensive care unit visiting policies in the United Kingdom. Anaesthesia 2010, 65:1101-1105

14. Curtis JR, Patrick DL, Shannon SE, Treece PD, Engelberg RA, Rubenfeld GD: The family conference as a focus to improve communication about endof-life care in the intensive care unit: opportunities for improvement. Crit Care Med 2001, 29:N26-N33.
15. Schweickert WD, Pohlman MC, Pohlman AS, Nigos C, Pawlik AJ, Esbrook CL, Spears L, Miller M, Franczyk M, Deprizio D, Schmidt GA, Bowman A, Barr R, McCallister KE, Hall JB, Kress JP: Early physical and occupational therapy in mechanically ventilated, critically ill patients: a randomised controlled trial. Lancet 2009, 373:1874-1882.

16. MacLaren R, Bond CA, Martin SJ, Fike D: Clinical and economic outcomes of involving pharmacists in the direct care of critically ill patients with infections. Crit Care Med 2008, 36:3184-3189.

17. Raineri E, Pan A, Mondello P, Acquarolo A, Candiani A, Crema L: Role of the infectious diseases specialist consultant on the appropriateness of antimicrobial therapy prescription in an intensive care unit. Am J Infect Control 2008, 36:283-290.

18. Hebert PC, Wells G, Blajchman MA, Marshall J, Martin C, Pagliarello G Tweeddale M, Schweitzer I, Yetisir E: A multicenter, randomized, controlled clinical trial of transfusion requirements in critical care. Transfusion Requirements in Critical Care Investigators, Canadian Critical Care Trials Group. N Engl J Med 1999, 340:409-417.

19. Acute Respiratory Distress Syndrome Network: Ventilation with lower tidal volumes as compared with traditional tidal volumes for acute lung injury and the acute respiratory distress syndrome. N Engl J Med 2000, 342:1301-1308.

20. Bellomo R, Chapman M, Finfer S, Hickling K, Myburgh J: Low-dose dopamine in patients with early renal dysfunction: a placebo-controlled randomised trial. Australian and New Zealand Intensive Care Society (ANZICS) Clinical Trials Group. Lancet 2000, 356:2139-2143.

21. Wheeler AP, Bernard GR, Thompson BT, Schoenfeld D, Wiedemann HP, deBoisblanc B, Connors AF, Jr, Hite RD, Harabin AL: Pulmonary-artery versus central venous catheter to guide treatment of acute lung injury. N Engl J Med 2006, 354:2213-2224

22. Girard TD, Kress JP, Fuchs BD, Thomason JW, Schweickert WD, Pun BT, Taichman DB, Dunn JG, Pohlman AS, Kinniry PA, Jackson JC, Canonico AE, Light RW, Shintani AK, Thompson JL, Gordon SM, Hall JB, Dittus RS, Bernard GR, Ely EW: Efficacy and safety of a paired sedation and ventilator weaning protocol for mechanically ventilated patients in intensive care (Awakening and Breathing Controlled trial): a randomised controlled trial. Lancet 2008, 371:126-134.

23. Van den Berghe $G$, Wouters $P$, Weekers F, Verwaest C, Bruyninckx F, Schetz M, Vlasselaers D, Ferdinande P, Lauwers P, Bouillon R: Intensive insulin therapy in the critically ill patients. N Eng/ J Med 2001, 345:1359-1367.

24. Finfer S, Chittock DR, Su SY, Blair D, Foster D, Dhingra V, Bellomo R, Cook D, Dodek P, Henderson WR, Hebert PC, Heritier S, Heyland DK, McArthur C, McDonald E, Mitchell I, Myburgh JA, Norton R, Potter J, Robinson BG, Ronco $\mathrm{JJ}$ : Intensive versus conventional glucose control in critically ill patients. NEngl J Med 2009, 360:1283-1297.

25. Annane D, Sebille V, Charpentier C, Bollaert PE, Francois B, Korach JM, Capellier G, Cohen Y, Azoulay E, Troche G, Chaumet-Riffaud P, Bellissant E: Effect of treatment with low doses of hydrocortisone and fludrocortisone on mortality in patients with septic shock. JAMA 2002, 288:862-871.

26. Sprung CL, Annane D, Keh D, Moreno R, Singer M, Freivogel K, Weiss YG, Benbenishty J, Kalenka A, Forst H, Laterre PF, Reinhart K, Cuthbertson BH, Payen D, Briegel J: Hydrocortisone therapy for patients with septic shock. NEngl J Med 2008, 358:111-124.

27. Bernard GR, Vincent JL, Laterre PF, LaRosa SP, Dhainaut JF, Lopez-Rodriguez A Steingrub JS, Garber GE, Helterbrand JD, Ely EW, Fisher CJ, Jr: Efficacy and safety of recombinant human activated protein $\mathrm{C}$ for severe sepsis. N Engl J Med 2001, 344:699-709.

28. Ranieri VM, Thompson BT, Barie PS, Dhainaut JF, Douglas IS, Finfer S, Gardlund B, Marshall JC, Rhodes A, Artigas A, Payen D, Tenhunen J, Al-Khalidi HR, Thompson V, Janes J, Macias WL, Vangerow B, Williams MD: Drotrecogin alfa (activated) in adults with septic shock. N Engl J Med 2012, 366:2055-2064.

29. Levy MM, Fink MP, Marshall JC, Abraham E, Angus D, Cook D, Cohen J, Opal SM, Vincent JL, Ramsay G: 2001 SCCM/ESICM/ACCP/ATS/SIS International Sepsis Definitions Conference. Crit Care Med 2003, 31:1250-1256.

30. Ranieri VM, Rubenfeld GD, Thompson BT, Ferguson ND, Caldwell E, Fan E, Camporota L, Slutsky AS: Acute respiratory distress syndrome: the Berlin Definition. JAMA 2012, 307:2526-2533.

31. Knaus WA, Draper EA, Wagner DP, Zimmerman JE: APACHE II: a severity of disease classification system. Crit Care Med 1985, 13:818-829.

32. Le Gall JR, Lemeshow S, Saulnier F: A new Simplified Acute Physiology Score (SAPS II) based on a European/North American multicenter study. JAMA 1993, 270:2957-2963. 
33. Vincent $J$, Moreno R, Takala J, Willatts $S$, De Mendonca A, Bruining H, Reinhart CK, Suter PM, Thijs LG: The SOFA (Sepsis-related Organ Failure Assessment) score to describe organ dysfunction/failure. On behalf of the Working Group on Sepsis-Related Problems of the European Society of Intensive Care Medicine. Intensive Care Med 1996, 22:707-710.

34. Howell MD, Talmor D, Schuetz P, Hunziker S, Jones AE, Shapiro NI: Proof of principle: the predisposition, infection, response, organ failure sepsis staging system. Crit Care Med 2011, 39:322-327.

35. Dellinger RP, Levy MM, Carlet JM, Bion J, Parker MM, Jaeschke R, Reinhart K, Angus DC, Brun-Buisson C, Beale R, Calandra T, Dhainaut JF, Gerlach H, Harvey M, Marini JJ, Marshall J, Ranieri M, Ramsay G, Sevransky J, Thompson BT, Townsend S, Vender JS, Zimmerman JL, Vincent JL: Surviving Sepsis Campaign: international guidelines for management of severe sepsis and septic shock: 2008. Crit Care Med 2008, 36:296-327.

36. Heyland DK, Dhaliwal R, Drover JW, Gramlich L, Dodek P: Canadian clinical practice guidelines for nutrition support in mechanically ventilated, critically ill adult patients. JPEN J Parenter Enteral Nutr 2003, 27:355-373

37. Napolitano LM, Kurek S, Luchette FA, Corwin HL, Barie PS, Tisherman SA Hebert PC, Anderson GL, Bard MR, Bromberg W, Chiu WC, Cipolle MD, Clancy KD, Diebel L, Hoff WS, Hughes KM, Munshi I, Nayduch D, Sandhu R, Yelon JA: Clinical practice guideline: red blood cell transfusion in adult trauma and critical care. Crit Care Med 2009, 37:3124-3157.
38. Thompson DR, Hamilton DK, Cadenhead CD, Swoboda SM, Schwindel SM, Anderson DC, Schmitz EV, St Andre AC, Axon DC, Harrell JW, Harvey MA, Howard A, Kaufman DC, Petersen C: Guidelines for intensive care unit design. Crit Care Med 2012, 40:1586-1600.

39. Vincent $\mathrm{J}$ : Give your patient a fast hug (at least) once a day. Crit Care Med 2005, 33:1225-1229.

40. Halpern NA, Pastores SM: Critical care medicine in the United States 20002005: an analysis of bed numbers, occupancy rates, payer mix, and costs. Crit Care Med 2010, 38:65-71.

41. Krell K: Critical care workforce. Crit Care Med 2008, 36:1350-1353.

42. Kahn JM: Volume, outcome, and the organization of intensive care. Crit Care 2007, 11:129.

43. Breslow MJ, Rosenfeld BA, Doerfler M, Burke G, Yates G, Stone DJ, Tomaszewicz P, Hochman R, Plocher DW: Effect of a multiple-site intensive care unit telemedicine program on clinical and economic outcomes: an alternative paradigm for intensivist staffing. Crit Care Med 2004, 32:31-38.

doi:10.1186/cc11500

Cite this article as: Vincent $J$ : Critical care - where have we been and where are we going? Critical Care 2013, 17(Suppl 1):S2. 